\title{
Drip Fertigation Effects on Quality Characters of Elephant Foot Yam and Water Use Efficiency of Elephant Foot Yam+Green Gram Intercropping System
}

\author{
S.K. Jata ${ }^{1}$, M. Nedunchezhiyan ${ }^{1 *}$, S.K. Maity ${ }^{2}$ and M. Mallikarjun ${ }^{2}$ \\ ${ }^{1}$ Regional Centre of ICAR-Central Tuber Crops Research Institute, Bhubaneswar \\ ${ }^{2}$ Institute of Agriculture, Visva-Bharati, Sriniketan-731 236, West Bengal, India \\ *Corresponding author
}

\section{A B S T R A C T}

\begin{tabular}{|l|}
\hline Keyw or d s \\
Amorphophallus \\
paeoniifolius, \\
Protein, Starch, \\
System productivity \\
\hline Article Info \\
\hline $\begin{array}{l}\text { Accepted: } \\
15 \text { July } 2020 \\
\text { Available Online: } \\
10 \text { August } 2020\end{array}$ \\
\hline
\end{tabular}

A field experiment was conducted during 2013 and 2014 at the Regional Centre of ICARCentral Tuber Crops Research Institute, Dumuduma, Bhubaneswar, Odisha to study the drip fertigation effects on quality characters of elephant foot yam [Amorphophallus paeoniifolius (Dennst.) Nicolson] and water use efficiency of elephant foot yam+green gram (Vigna radiata L.) intercropping system. The experiment was laid out in randomized block design with four replications. The experiment consisted of six treatments i.e. $\mathrm{T}_{1}$-Soil application of fertilizers $\mathrm{N}-\mathrm{K}_{2} \mathrm{O} @ 100-100 \mathrm{~kg} \mathrm{ha}^{-1}, \mathrm{~T}_{2}$-Fertigation of $\mathrm{N}-\mathrm{K}_{2} \mathrm{O} @ 60-60 \mathrm{~kg}$ $\mathrm{ha}^{-1}, \mathrm{~T}_{3}$-Fertigation of $\mathrm{N}-\mathrm{K}_{2} \mathrm{O} @ 80-80 \mathrm{~kg} \mathrm{ha}^{-1}$, T4-Fertigation of $\mathrm{N}-\mathrm{K}_{2} \mathrm{O} @ 100-100 \mathrm{~kg} \mathrm{ha}$ ${ }^{1}$, T5-Fertigation of $\mathrm{N}-\mathrm{K}_{2} \mathrm{O} @ 120-120 \mathrm{~kg} \mathrm{ha}^{-1}$ and T6-Fertigation of $\mathrm{N}-\mathrm{K}_{2} \mathrm{O} @ 140-140 \mathrm{~kg}$ $\mathrm{ha}^{-1}$. During the final land preparation FYM @ $10 \mathrm{tha}^{-1}$ was applied along with $\mathrm{P}_{2} \mathrm{O}_{5} @ 80$ $\mathrm{kg} \mathrm{ha}^{-1}$ as single super phosphate (SSP), borax @ $10 \mathrm{~kg} \mathrm{ha}^{-1}$ and zinc sulphate @ $10 \mathrm{~kg} \mathrm{ha}^{-1}$ in all the treatments. The result revealed that increasing fertigation level increased nutritional status. Greater amount of protein, sugar, starch and mineral nutrient yields were noticed in the treatment $T_{6}$ followed by $T_{5}$ during both the years of study. The system productivity and water use efficiency were also greater in treatment $T_{6}$. However the difference between $T_{6}$ and $T_{5}$ was negligible during both the years of study. Thus, the treatment fertigation of $\mathrm{N}-\mathrm{K}_{2} \mathrm{O} @ 120-120 \mathrm{~kg} \mathrm{ha}^{-1}\left(\mathrm{~T}_{5}\right)$ was found optimum for elephant foot yam+green gram intercropping system.

\section{Introduction}

The elephant foot yam [Amorphophallus paeoniifolius (Dennst.) Nicolson (Aracea)], is regarded as king of tuber crops due to its high yield potential and profitability (Nedunchezhiyan and Byju, 2005). Elephant foot yam is a rich source of different minerals such as potassium, calcium, phosphorus, iron, zinc and selenium. The corm also supplies several vitamins like vitamin $\mathrm{A}, \mathrm{C}$ and $\mathrm{B} 6$ (Chowdhury and Hussain, 1979; Sakai, 1983; Bradbury and Holloway, 1988; Parkinson, 1984; Mukhopadhyay and Sen, 1999). It provides energy about $330 \mathrm{KJ} / 100 \mathrm{~g}$. It contains $72-79 \%$ moisture, $18-24 \%$ 
carbohydrate, $1.7-5.0 \%$ protein, $0.2-0.4 \%$ fats and $0.8 \%$ edible fibre. It contains omega-3 fatty acids and diosgenin, a molecular hormone which has potential anticancer effect. Bradbury and Holloway (1988) reported that elephant foot yam used as carminative, expectorant, restorative, stomachic and tonic. It is dried and used in the treatment of piles and dysentery. It reduces cholesterol levels in blood, acts as an anticoagulant. It can be safely consumed by diabetic people, helps to maintain the hormonal balance by increasing the estrogen level in women. It can relieve the women from pre-menstrual syndrome as well; haemorrhoids patients are also prescribed to have elephant yam (Bradbury and Holloway, 1988). Chowdhury and Hussain (1979) reported that the elephant foot yam consumed by people looking for weight reduction as it is low in fat content $(0.2-0.4 \%)$. Because of its wide medicinal benefits and nutritional profile, elephant yam is considered as a potential nutritious and curative food.

In India, elephant foot yam is cultivated mainly in Andhra Pradesh, Gujarat, Maharashtra, West Bengal, North-Eastern states, Kerala, Bihar and Uttar Pradesh (Nedunchezhiyan, 2014a). It is planted at wider spacing. It takes three months to fully cover the ground and that allows intercrop to grow in wider spaces. There is a great possibility for utilizing the interspaces of elephant foot yam during early growth stage by growing short duration cucurbitaceous vegetable crops like bitter gourd (Momordica charantia L.), ridge gourd (Luffa acutangula L.), bottle gourd (Lagenaria siceraria L.), etc (Chattopadhyay et al., 2008 and Singh et al., 2013). Intercropping green gram (Vigna radiata L.) was found suitable in elephant foot yam (Nedunchezhiyan and Byju 2005; Jata et al., 2018a and 2018b). Incidence of collar rot was found decreased in elephant foot yam + turmeric (Curcuma longa L.) (1:2) intercropping (Nedunchezhiyan, 2014b). The intercropping systems showed superiority to sole cropping in starch content and reduction in calcium oxalate content in the corms of elephant foot yam (Nedunchezhiyan, 2014b).

Nutrients are pre-requisites for enhancing quantity and quality of crop yields (Achakzai et al., 2012). Fertigation is a method of application of fertilizers through irrigation, which enables adequate supply of water and nutrients with precise timing and uniform distribution to meet the crop requirement to get maximum yield (Patel and Rajput, 2000; Chawla and Narda, 2002; Nedunchezhiyan, 2017). Drip fertigation is considered to be the most efficient in saving of water (Behera et al., 2013). In elephant foot yam, drip fertigation saved water 4,341,000 L/ha (Nedunchezhiyan et al., 2017). Elephant foot yam+green gram intercropping system is getting popular in India (Nedunchezhiyan et al., 2008). Though few studies on fertility management for elephant foot yam+green gram intercropping system is available, research work on effect of drip fertigation on quality of elephant foot yam and water use efficiency is not available. Keeping the above in view, an investigation was carried-out to find the effects of fertigation on quality of elephant foot yam and water use efficiency of elephant foot yam+green gram intercropping system.

\section{Materials and Methods}

A field experiment was conducted during 2013 and 2014 at the Regional Centre of ICAR-Central Tuber Crops Research Institute $\left(20^{\circ} 14^{\prime} \mathrm{N}\right.$ and $85^{\circ} 47^{\prime} \mathrm{E}$ at $33 \mathrm{~m}$ above mean sea level), Dumuduma, Bhubaneswar, Odisha. The soil of the experimental site was sandy clay loam in texture. The soil was low in organic carbon $(0.42 \%)$, available nitrogen (93.5 $\mathrm{kg} \mathrm{ha}^{-1}$ ) and available potassium (89.4 $\mathrm{kg} \mathrm{ha}^{-1}$ ) and medium in available phosphorus 
$\left(12.6 \mathrm{~kg} \mathrm{ha}^{-1}\right)$ with normal soil reaction $(\mathrm{pH}$ 6.8). The climate condition of the area is warm and moist with hot and humid summer and mild winter. The average annual rainfall of the experimental site is $1693.5 \mathrm{~mm}$ out of which nearly $80 \%$ is received during June to September. The experiment elephant foot yam+green gram intercropping was laid out in randomized block design with four replications. The experiment consisted of six treatments i.e. $\mathrm{T}_{1}$-Soil application of fertilizers $\mathrm{N}-\mathrm{K}_{2} \mathrm{O} @ 100-100 \mathrm{~kg} \mathrm{ha}^{-1}, \mathrm{~T}_{2^{-}}$ Fertigation of $\mathrm{N}-\mathrm{K}_{2} \mathrm{O} @ 60-60 \mathrm{~kg} \mathrm{ha}^{-1}, \mathrm{~T}_{3}$ Fertigation of $\mathrm{N}-\mathrm{K}_{2} \mathrm{O} @ 80-80 \mathrm{~kg} \mathrm{ha}^{-1}$, T4Fertigation of $\mathrm{N}-\mathrm{K}_{2} \mathrm{O} @ 100-100 \mathrm{~kg} \mathrm{ha}^{-1}$, T5Fertigation of $\mathrm{N}-\mathrm{K}_{2} \mathrm{O} @ 120-120 \mathrm{~kg} \mathrm{ha}^{-1}$ and T6-Fertigation of $\mathrm{N}-\mathrm{K}_{2} \mathrm{O} @ 140-140 \mathrm{~kg} \mathrm{ha}^{-1}$. During the final land preparation FYM @ $10 \mathrm{t}$ ha ${ }^{-1}$ was applied along with $\mathrm{P}_{2} \mathrm{O}_{5} @ 80 \mathrm{~kg} \mathrm{ha}^{-1}$ as single super phosphate (SSP), borax @10 $\mathrm{kg} \mathrm{ha}^{-1}$ and zinc sulphate @ $10 \mathrm{~kg} \mathrm{ha}^{-1}$ in all the treatments. The $1^{\text {st }}$ season elephant foot yam crop was planted on $18^{\text {th }}$ April 2013 and the $2^{\text {nd }}$ season crop was planted on $16^{\text {th }}$ April 2014. The elephant foot yam (var. Gajendra) seed weighing 400-500 $\mathrm{g}$ was planted at the spacing of $90 \times 90 \mathrm{~cm}$ on the ridges bellow 5 to $10 \mathrm{~cm}$ depth of the soil with the help of spade. The green gram (var. Dauli) seeds were sown $\left(5 \mathrm{~kg} \mathrm{ha}^{-1}\right)$ continuously on single row on the top of the ridges immediately after planting of elephant foot yam. After 15 days of sowing green gram plants were thinned 15 $\mathrm{cm}$ apart. In soil application treatment the nutrient $\mathrm{N}$ as urea and $\mathrm{K}_{2} \mathrm{O}$ as muriate of potash (MOP) were applied in three equal splits at 45, 75 and 105 days after planting (DAP) by band placement around elephant foot yam just after weeding followed by earthing up. In fertigation treatments the nutrient $\mathrm{N}$ as urea and $\mathrm{K}_{2} \mathrm{O}$ as water soluble sulphate of potash (SOP) were applied in five equal splits at 15, 45, 75, 105 and 135 DAP along with irrigation water through drip. The required quantity of urea and sulphate of potash as per the treatments were dissolved separately in a plastic bucket and dilute it at 1:5 (w/v) proportions of fertilizer and water. The scheduled quantity of fertilizers solution was given through ventury system for each treatment separately. After complete of fertigation normal water was passing through the ventury for 5 minutes to avoid treatment contamination. A valve was provided at the beginning of each lateral of each plot for controlled fertigation. The drippers were fixed on the laterals in such a way that each elephant foot yam plant was covered by two drippers with the spacing of $15 \mathrm{~cm}$. The drip irrigation at $80 \%$ cumulative pan evaporation was applied at every three days interval during dry spells. A total of 202.8 and 213.9 $\mathrm{mm}$ water was applied during dry spells of 2013 and 2014, respectively.

The fully matured green gram pods were plucked at $60^{\text {th }}$ and $75^{\text {th }}$ days after sowing (DAS). The haulms of the green gram were left in the field and trampled them to act as mulch. The elephant foot yam crop was harvested at $8^{\text {th }}$ months after planting (MAP) i.e., $17^{\text {th }}$ December 2013 and $15^{\text {th }}$ December 2014 of $1^{\text {st }}$ and $2^{\text {nd }}$ season crops, respectively. Growth observations of green gram were recorded at $75^{\text {th }}$ DAS and yield attributes and yield at harvest. The elephant foot yam growth observations were recorded at $5^{\text {th }}$ MAP, dry matter production and partitioning was carried out at $3^{\text {rd }}, 5^{\text {th }}$ and $8^{\text {th }}$ MAP and yield attributes and yield at $8^{\text {th }}$ MAP. Sugar, starch and oxalate content of elephant foot yam corm were determined on fresh weight basis by following the standard procedure described by Moorthy and Padmaja (2002). The mineral elements $\mathrm{N}, \mathrm{P}$ and $\mathrm{K}$ were analysed by following standard procedures and expressed on dry weight basis. The $\mathrm{Ca}$, $\mathrm{Mg}$ and $\mathrm{Zn}$ contents of elephant foot yam corm were determined by using atomic absorption spectro photometer from the digested samples used for analysis of $\mathrm{P}$ and $\mathrm{K}$ and expressed on dry weight basis. The 
protein content was obtained by multiplying the total nitrogen content of corm with a factor 6.25 (Ainara et al., 2013) and expressed on dry weight basis. The nutritional yields were computed by nutrient content of corms multiplied with dry matter/corm yield per ha. System productivity (SP) and water use efficiency (WUE) were computed as follows:

$\mathrm{SP}\left(\mathrm{tha}^{-1}\right)=$ Corm yield of elephant foot yam $\left(\mathrm{t} \mathrm{ha}^{-1}\right)+$

Seed yield of $\times$ Price of green green gram $\left(\mathrm{t} \mathrm{ha}^{-1}\right) \quad \operatorname{gram}\left(\mathrm{Rs} \mathrm{t}^{-1}\right)$

Price of elephant foot yam $\left(\mathrm{Rs} \mathrm{t}^{-1}\right)$

WUE $\left(\mathrm{kg} \mathrm{ha-} \mathrm{cm}^{-1}\right)=\frac{\text { System productivity }\left(\mathrm{kg} \mathrm{ha}^{-1}\right)}{\text { Amount of water applied }(\mathrm{cm})}$

The data were statistically analyzed and significance between mean differences among treatments for various parameters was analyzed using critical differences (CD) at 0.05 probability level.

\section{Results and Discussion}

\section{Nutritional value of elephant foot yam corms}

The drip fertigation effects on nutritional parameters like protein, sugar, starch, oxalate and mineral elements such as $\mathrm{Ca}, \mathrm{Mg}$ and $\mathrm{Zn}$ contents in elephant foot yam corms were presented in the Table 1. The levels of fertigation significantly influenced the protein percentage of the corm during both the years. However, the year 2014 recorded higher mean value compared to the year 2013. The highest protein percentage was recorded with treatment $\mathrm{T}_{6}$ which was significantly higher over all other levels of fertigation during both the year of experimentation. Cable (1975) also observed that protein content of corm was increased through nitrogen fertilization. The lower protein percentage was observed with the treatment $T_{2}$ which was relatively lower than $\mathrm{T}_{1}, \mathrm{~T}_{3}$ and $\mathrm{T}_{4}$ in the year 2013 and significantly lower than other levels of fertigation in the year 2014. The levels of fertigation had no significant influence on the sugar percentage of the corm during both the years. However, the year 2013 recorded higher mean value compared to the year 2014 . The treatment $T_{1}$ recorded lower sugar percentage than all other levels of fertigation. The levels of fertigation had no significant influence on the starch percentage of the corm during both the years. However, the year 2014 recorded higher mean value compared to the year 2013. However, the highest starch percentage was recorded with treatment $\mathrm{T}_{5}$ $(15.7 \%)$ in the year 2013 and with treatment $\mathrm{T}_{3}(16.2 \%)$ in the year 2014. Patel and Mehta (1987) reported an application of $\mathrm{N}$ increased the starch contents of the corms. Ashokan et al., (1984) observed the starch content of tuber increased with increasing levels of $\mathrm{N}$ and $\mathrm{K}_{2} \mathrm{O}$ in sweet potato (Ipomoea batatas L.). Mukhopadhyay and Sen (1986) reported that quality of corms improved with increasing levels of both $\mathrm{N}$ and $\mathrm{K}$. The levels of fertigation showed significant effect on the oxalate content of the corm during both the years. The year 2013 recorded low oxalate mean value compared to the year 2014. All the levels of fertigation recorded significantly lower oxalate content values than soil application of NK fertilizers. The less oxalate content values were observed with the increase in the levels of fertigation. The relatively lower oxalate content value was recorded with the treatment $\mathrm{T}_{5}$ and with treatment $\mathrm{T}_{6}$ for the year 2013 and 2014, respectively. Ambarwati and Murti (2001) reported that corm yield (diameter and weight) of Amorphophallus variabilis negatively correlated with corm oxalate content. Nedunchezhiyan et al., (2018) reported dilution effect of oxalate content in elephant foot yam corm. However, the increasing of corm size was not always 
followed by the decreasing of corm oxalate content and vice versa. This fact was appropriate with the report of Indriyani et al., (2010) that mentioned there was difference of oxalate content based on corm size, but its correlation was not linear. Soil factors seemingly affect more oxalate content than climate factors. Palaniswamy et al., (2002 and 2004) explained that oxalic acid was influenced by nitrogen (soil mineral). Some researchers reported that oxalate content different for any kind of plant species depend on age, physiology, environment, and genetic (Libert and Franceschi, 1987).

The levels of fertigation significantly influenced the phosphorous percentage of the corm during both the years. However, both the years recorded same mean values. The highest phosphorous percentage was recorded with treatment $T_{6}$ which was significantly higher over all other levels of fertigation during both the years of experimentation. The lower phosphorous percentage was observed with the treatment $T_{2}$ which was relatively less than the $T_{3}$ and $T_{4}$ in the year 2013 and significantly lower than other levels of fertigation in the year 2014. The levels of fertigation significantly influenced the potassium percentage of the corm during both the years. However, both the years recorded same mean values. The highest potassium percentage was recorded with treatment $T_{6}$ which was significantly higher over all other levels of fertigation during both the years of experimentation. Patel and Mehta (1987) reported an application of $\mathrm{N}$ increased the $\mathrm{P}$ and $\mathrm{K}$ contents of the corms. Mukhopadhyay and Sen (1986) reported that quality of corms improved with increasing levels of both $\mathrm{N}$ and $\mathrm{K}$. The lower potassium percentage was observed with the treatment $\mathrm{T}_{2}$ which was relatively less than $T_{1}, T_{3}$ and $T_{4}$ in the year 2013 and significantly lower than other levels of fertigation in the year 2014. The levels of fertigation significantly influenced the calcium content of the corm during year 2014 only. The higher calcium content was recorded with treatment $T_{1}$ during both the years of experimentation. The treatment $T_{5}$ recorded relatively lower calcium content for both the years which was at par with treatment $T_{6}$ in the year 2014. The levels of fertigation significantly influenced the magnesium content of the corm during year 2014 only. The higher magnesium content was recorded with treatment $T_{3}$ and $T_{1}$ for the year 2013 and 2014 respectively. The treatments $T_{2}, T_{3}$ and $T_{4}$ were at par with the treatment $T_{1}$ for the year 2014. The treatment $\mathrm{T}_{5}$ recorded lower magnesium content for both the years. The levels of fertigation significantly influenced the zinc content of the corm during year 2014 only. The year 2014 recorded higher mean value than the year 2013. However, no particular trend was observed. The higher zinc content was recorded with treatment $T_{3}$ for both the years. The relatively lower zinc content was recorded with the treatment $\mathrm{T}_{4}$ for the year 2013 and with the treatment $T_{2}$ for the year 2014.

\section{Nutritional yield of elephant foot yam}

Nutritional yield per ha is more important than content in elephant foot yam. The drip fertigation effects on nutritional yields per ha of elephant foot yam were presented in the Table 2. The levels of fertigation influenced the protein yield during both the years. During the years 2013 and 2014, it was ranged 95.3-140.6 and 93.7-149.1 $\mathrm{kg} \mathrm{ha}^{-1}$, respectively (Table 2). The highest protein yield was with $T_{6}$ and the lowest was with $T_{1}$. Corm yield influenced the protein yield apart from protein content in the corms. The levels of fertigation influenced sugar yield during both the years. During the years 2013 and 2014 , it was ranged 259-385 and 257-356 kg ha $^{-1}$, respectively (Table 2). The lowest was being with $T_{1}$. This could be due to lower 
elephant foot yam corm yield. The starch yield was influenced by fertigation levels and it was ranged 4087-5652 and 4455-5702 kg $\mathrm{ha}^{-1}$ during the year 2013 and 2014, respectively (Table 2). The lower starch yield was recorded in $\mathrm{T}_{1}$ due to lower corm yield. Thus soil application of nutrients (NK) resulted in lower corm yield correspondingly lower protein, sugar and starch yields were registered. The oxalate yield was ranged 23.526.9 and $25.2-26.9 \mathrm{~kg} \mathrm{ha}^{-1}$ during the year 2013 and 2014, respectively (Table 2). The lower oxalate yield was noticed in the treatment $\mathrm{T}_{1}$ due to lower corm yield. Singh et al., (1989) reported the highest yields of high quality corms of elephant foot yam were obtained with $50 \%$ trickle applied $\mathrm{N}+\mathrm{K}$ grown on polyethylene mulched beds.

The $\mathrm{P}$ and $\mathrm{K}$ mineral yields were influenced by fertigation levels (Table 2). The $\mathrm{P}$ mineral yield ranged 3.0-9.1 and 3.1-9.3 kg ha during the year 2013 and 2014, respectively. The $\mathrm{K}$ mineral yield ranged 34.0-85.1 and $32.5-100.3 \mathrm{~kg} \mathrm{ha}^{-1}$ during the year 2013 and 2014, respectively. Both $\mathrm{P}$ and $\mathrm{K}$ mineral yields were higher with $\mathrm{T}_{6}$ and lower with $\mathrm{T}_{1}$. This was owing to corm yields. The $\mathrm{Ca}, \mathrm{Mg}$ and $\mathrm{Zn}$ mineral yields were also influenced by fertigation levels (Table 2). The $\mathrm{Ca}$ mineral yield ranged 5.2-6.3 and 5.4-6.2 $\mathrm{kg} \mathrm{ha}^{-1}$ during the year 2013 and 2014, respectively. The $\mathrm{Mg}$ mineral yield ranged 2.5-3.1 and 2.7$3.3 \mathrm{~kg} \mathrm{ha}^{-1}$ during the year 2013 and 2014, respectively. The $\mathrm{Zn}$ mineral yield ranged 0.05-0.06 and $0.06-0.08 \mathrm{~kg} \mathrm{ha}^{-1}$ during the year 2013 and 2014, respectively. The $\mathrm{Ca}, \mathrm{Mg}$ and $\mathrm{Zn}$ mineral yields were lower with $\mathrm{T}_{1}$, owing to corm yields. The higher level was not followed any trend due to variation of nutrient content in corms and corm yields. Ukom et al., (2009) reported the uptake of varied levels of minerals phosphorous, calcium, magnesium and zinc on application of varied levels of nitrogen containing fertilizer.

\section{System productivity and WUE}

The system productivity was significantly influenced by fertigation levels (Table 3 ). The system productivity was higher in the treatment $\mathrm{T}_{6}$ in both the years and it was statistically on par with $\mathrm{T}_{5}$ and $\mathrm{T}_{4}$ during the year 2013 and $\mathrm{T}_{5}, \mathrm{~T}_{4}$ and $\mathrm{T}_{3}$ during the year 2014. Nedunchezhiyan et al., (2008) also reported that increasing fertility level increased the system productivity of elephant foot yam+green gram intercropping system. The system productivity of the treatments $T_{6}$ and $\mathrm{T}_{5}$ was same during 2014 and had negligible difference during 2013. Hence, we could consider the treatment $\mathrm{T}_{5}$ was the best fertigation treatment for elephant foot yam+green gram intercropping system. The system productivity of the treatment $\mathrm{T}_{5}$ was 22.1 and $24.7 \%$ higher during the year 2013 and 2014, respectively than $\mathrm{T}_{1}$. Elephant foot yam is a long duration crop, which can uptake nutrients up to $6 \mathrm{MAP}$. In the present experiment in $T_{1}$, the last dose of nutrients was applied at 105 DAP. The nutrient applied in the soil was subjected to various losses before plant uptake. Hence plant could not utilize the applied entire nutrients resulted in lower elephant foot yam corm yield. In treatment $\mathrm{T}_{5}$, the last dose nutrients was applied at 135 DAP through drip irrigation. All the nutrients were reached root zone and the crop effectively utilized the same resulted in greater corm yield. Nedunchezhiyan et al., (2016 and 2017) also reported similar findings in elephant foot yam.

The WUE of elephant foot yam+green gram intercropping system was significantly influenced by fertigation levels (Table 3 ). The WUE was higher in the treatment $T_{6}$ in both the years and it was statistically on par with $\mathrm{T}_{5}$ and $\mathrm{T}_{4}$ during the year 2013 and $\mathrm{T}_{5}, \mathrm{~T}_{4}$ and $\mathrm{T}_{3}$ during the year 2014 . 
Table.1 Effect of fertigation on nutrient content of elephant foot yam in elephant foot yam + greengram intercropping

\begin{tabular}{|c|c|c|c|c|c|c|c|c|c|c|c|c|c|c|c|c|c|c|}
\hline \multirow[t]{3}{*}{ Treatment } & \multicolumn{18}{|c|}{ Nutrient content of corm } \\
\hline & \multicolumn{2}{|c|}{ Protein $(\%)$} & \multicolumn{2}{|c|}{ Sugar $(\%)$} & \multicolumn{2}{|c|}{ Starch $(\%)$} & \multicolumn{2}{|c|}{ 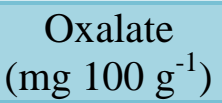 } & \multicolumn{2}{|c|}{$\mathrm{P}(\%)$} & \multicolumn{2}{|c|}{$\mathrm{K}(\%)$} & \multicolumn{2}{|c|}{$\begin{array}{l}\text { Calcium } \\
\left(\mathrm{mg} 100 \mathrm{~g}^{-1}\right)\end{array}$} & \multicolumn{2}{|c|}{ 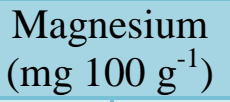 } & \multicolumn{2}{|c|}{$\begin{array}{c}\text { Zinc } \\
\left(\mathrm{mg} 100 \mathrm{~g}^{-1}\right)\end{array}$} \\
\hline & 2013 & 2014 & 2013 & 2014 & 2013 & 2014 & 2013 & 2014 & 2013 & 2014 & 2013 & 2014 & 2013 & 2014 & 2013 & 2014 & 2013 & 2014 \\
\hline $\mathbf{T}_{1}$ & 1.70 & 1.66 & 0.88 & 0.87 & 13.90 & 15.10 & 79.90 & 85.50 & 0.07 & 0.07 & 0.75 & 0.76 & 93.10 & 95.00 & 45.00 & 47.30 & 0.87 & 1.08 \\
\hline $\mathbf{T}_{2}$ & 1.30 & 1.20 & 1.03 & 1.08 & 15.20 & 15.10 & 76.60 & 79.20 & 0.05 & 0.05 & 0.56 & 0.53 & 90.40 & 92.90 & 40.80 & 46.00 & 0.89 & 0.92 \\
\hline $\mathbf{T}_{3}$ & 1.50 & 1.50 & 1.04 & 0.91 & 15.00 & 16.20 & 75.10 & 76.50 & 0.06 & 0.06 & 0.67 & 0.64 & 91.70 & 92.90 & 46.80 & 45.10 & 0.92 & 1.20 \\
\hline $\mathbf{T}_{4}$ & 1.50 & 1.68 & 1.00 & 0.94 & 15.10 & 15.60 & 73.80 & 74.80 & 0.06 & 0.07 & 0.65 & 0.72 & 92.70 & 94.00 & 44.30 & 46.40 & 0.82 & 0.93 \\
\hline $\mathbf{T}_{5}$ & 1.90 & 1.85 & 1.07 & 0.87 & 15.70 & 15.30 & 73.60 & 72.20 & 0.09 & 0.08 & 0.85 & 0.81 & 86.90 & 85.30 & 40.70 & 39.70 & 0.89 & 0.94 \\
\hline$T_{6}$ & 2.00 & 2.08 & 0.95 & 0.97 & 14.90 & 15.20 & 74.20 & 71.90 & 0.13 & 0.13 & 1.21 & 1.40 & 87.00 & 86.10 & 44.70 & 43.30 & 0.86 & 0.94 \\
\hline CD (0.05) & 0.40 & 0.19 & NS & NS & NS & NS & 3.50 & 4.00 & 0.02 & 0.01 & 0.20 & 0.11 & NS & 5.90 & NS & 3.60 & NS & 0.16 \\
\hline
\end{tabular}

Table.2 Effect of fertigation on nutrient yield of elephant foot yam in elephant foot yam + greengram intercropping

\begin{tabular}{|c|c|c|c|c|c|c|c|c|c|c|c|c|c|c|c|c|c|c|}
\hline \multirow[t]{3}{*}{ Treatment } & \multicolumn{18}{|c|}{ Nutrient yield $\left(\mathrm{kg} \mathrm{ha}^{-1}\right)$} \\
\hline & \multicolumn{2}{|c|}{ Protein } & \multicolumn{2}{|c|}{ Sugar } & \multicolumn{2}{|c|}{ Starch } & \multicolumn{2}{|c|}{ Oxalate } & \multicolumn{2}{|c|}{$\mathrm{P}$} & \multicolumn{2}{|c|}{$\mathrm{K}$} & \multicolumn{2}{|c|}{ Calcium } & \multicolumn{2}{|c|}{ Magnesium } & \multicolumn{2}{|c|}{ Zinc } \\
\hline & 2013 & 2014 & 2013 & 2014 & 2013 & 2014 & 2013 & 2014 & 2013 & 2014 & 2013 & 2014 & 2013 & 2014 & 2013 & 2014 & 2013 & 2014 \\
\hline $\mathbf{T}_{1}$ & 95.3 & 93.7 & 259 & 257 & 4087 & 4455 & 23.5 & 25.2 & 3.9 & 4 & 42 & 42.9 & 5.2 & 5.4 & 2.5 & 2.7 & 0.05 & 0.06 \\
\hline $\mathbf{T}_{2}$ & 78.8 & 73.5 & 333 & 353 & 4910 & 4938 & 24.7 & 25.9 & 3 & 3.1 & 34 & 32.5 & 5.5 & 5.7 & 2.5 & 2.8 & 0.05 & 0.06 \\
\hline $\mathbf{T}_{\mathbf{3}}$ & 98.2 & 101.5 & 355 & 320 & 5115 & 5702 & 25.6 & 26.9 & 3.9 & 4.1 & 43.9 & 43.3 & 6 & 6.3 & 3.1 & 3.1 & 0.06 & 0.08 \\
\hline $\mathbf{T}_{4}$ & 102.7 & 117.6 & 353 & 339 & 5330 & 5632 & 26.1 & 27 & 4.1 & 4.9 & 44.5 & 50.4 & 6.3 & 6.6 & 3 & 3.3 & 0.06 & 0.07 \\
\hline $\mathbf{T}_{5}$ & 133.3 & 132 & 385 & 318 & 5652 & 5600 & 26.5 & 26.4 & 6.3 & 5.7 & 59.6 & 57.8 & 6.1 & 6.1 & 2.9 & 2.8 & 0.06 & 0.07 \\
\hline$T_{6}$ & 140.6 & 149.1 & 344 & 356 & 5394 & 5578 & 26.9 & 26.4 & 9.1 & 9.3 & 85.1 & 100.3 & 6.1 & 6.2 & 3.1 & 3.1 & 0.06 & 0.07 \\
\hline CD (0.05) & 32.2 & 17.8 & 34 & 36 & 512 & 524 & NS & NS & 0.2 & 0.2 & 3.0 & 4.1 & NS & NS & NS & NS & NS & NS \\
\hline
\end{tabular}


Table.3 Fertigation effects on elephant foot yam+greengram system productivity and water use efficiency

\begin{tabular}{|c|c|c|c|c|}
\hline \multirow[t]{2}{*}{ Treatments } & \multicolumn{2}{|c|}{ System productivity $\left(\mathrm{t} \mathrm{ha} \mathbf{~}^{-1}\right)$} & \multicolumn{2}{|c|}{ WUE $\left({\left.\mathrm{kg} \mathrm{ha}-\mathrm{cm}^{-1}\right)}^{-1}\right.$} \\
\hline & 2013 & 2014 & 2013 & 2014 \\
\hline$T_{1}$ & 29.8 & 30.0 & 761.4 & 634.8 \\
\hline$T_{2}$ & 32.7 & 33.4 & 836.8 & 705.4 \\
\hline $\mathbf{T}_{3}$ & 34.5 & 36.0 & 882.9 & 761.6 \\
\hline $\mathbf{T}_{4}$ & 35.7 & 36.7 & 913.2 & 775.6 \\
\hline $\mathbf{T}_{5}$ & 36.4 & 37.4 & 930.4 & 789.8 \\
\hline$T_{6}$ & 36.6 & 37.4 & 936.5 & 791.6 \\
\hline CD (0.05) & 1.1 & 19 & 28.3 & 40.4 \\
\hline
\end{tabular}

The difference in WUE of the treatments $\mathrm{T}_{6}$ and $\mathrm{T}_{5}$ was negligible during both the years. Hence, we could consider the treatment $\mathrm{T}_{5}$ was the best fertigation treatment for elephant foot yam+green gram intercropping system. The WUE of the treatment $\mathrm{T}_{5}$ was 22.2and $24.4 \%$ higher during the year 2013 and 2014, respectively than $T_{1}$.

In conclusion, the treatment fertigation of $\mathrm{N}$ $\mathrm{K}_{2} \mathrm{O} @ 120-120 \mathrm{~kg} \mathrm{ha}^{-1}\left(\mathrm{~T}_{5}\right)$ was found optimum for elephant foot yam+green gram intercropping system for getting nutritionally rich elephant foot yam corms, higher nutrient yields, system productivity and water use efficiency.

\section{References}

Achakzai A K, Habibullah K, Shah B H and Wahid M A. 2012. Effect of nitrogen fertilizer on the growth of mungbean (Vigna radiata L.) grown in Quetta. Pakistan J. Bot. 44(3): 981-7.

Ainara, L., Silvia, A., Carmen, J. M., Pedro A., Jose I. R. D. G., Patrick, R. and Requel L. 2013. Crud protein determination of potatoes by NRIS technology, Elsiver (Science direct) Proc. Tech. 8: 488-492.

Ambarwati, E. and Murti, R. H. 2001. Correlation analysis and path coefficient of agronomy character to chemical composition of iles-iles (Amorphophallus variabilis) corm. Agric. Sci. 8(2): 55-61.

Ashokan, P. K., Nair, V. R. and Geetha, K. 1984. Response of local and hybrid varieties of cassava on nutrient uptake, J. Root Crops 10: 55-57.

Behera M S, Verma O P, Mahapatra P K, Singandhupe R B and Kumar, A. 2013. Effect of irrigation and fertility levels on yield, quality and economics of Japanese mint (Mentha arvensis) under drip irrigation system. Indian J. Agron. 58(1): 109-113.

Bradbury, J. H. and W. D. Holloway. 1988. Chemistry of tropical root crops: significance for nutrition and agriculture in the Pacific. Australian Centre for International Agricultural Research, Canberra, Australia.

Cable, W. J. 1975. Potassium requirement of taro (Colocasia esculenta (L.) Schott.) in solution culture. Trop. Root Tuber Crops Newsletter 8: 39-40.

Chattopadhyay, A., Mukhopadhyay, S. K. and Nath, R. 2008. Short duration vegetables as intercrops in elephant foot yam in the Gangetic alluvium of West Bengal: Analysis of growth, yield and economics. J. Root Crops 34(1): 10-14.

Chawla J K and Narda, N K. 2002. Growth parameters of trickle fertigated potato. Indian J. Agric. Sci. 70(11): 747-752. 
Chowdhury, B. and Hussain. M. 1979. Chemical composition of the edible parts of aroids grown in Bangladesh. Indian J. Agr. Sci. 49: 110-115.

Indriyani, S., Mastuti, R. and Roosdiana, A. 2010. Oxalate content in porang (Amorphophallus muelleri Blume syn. A. oncophyllus Prain) corm. J. Biol. Res. 4(A): 99-102.

Jata, S.K., Nedunchezhiyan, M., Maity, S.K. and Mallikarjun, M. 2018a. Intercrop and drip irrigation effects on growth, yield, water-use efficiency and economics of elephant foot yam (Amorphophallus paeoniifolius). Indian J. Agron. 63(4): 506-512.

Jata, S.K., Nedunchezhiyan, M., Maity, S.K. and Mallikarjun. M. 2018b. Cropping system and irrigation effects on nutrient use efficiency and quality of elephant foot yam [Amorphophallus paeoniifolius (Dennst.) Nicolson]. EPlanet 16(1): 26-33.

Libert, B. and Franceschi, V. R. 1987. Oxalate in crop plants. J Agric Food Chem. 35: 926-938.

Moorthy, S. N. and Padmaja, G. 2002. A rapid titrimetric method for the determination of starch and sugar content of tuber crop. J. Root Crops 28: 31-38

Mukhopadhyay, S. K and Sen, H. 1999. Effect of Azotobacter on corm yield of elephant foot yam. J. Root Crops 25: 159-162.

Mukhopadhyay, S. K. and Sen, H. 1986. Effect of nitrogen and potassium on yield and quality of elephant foot yam (Amorphophallus campanulatus Blume). J. Root Crops 12(2): 103-106.

Nedunchezhiyan, M., Byju, G., Ravi, V. and James George. 2017. Spacio-temporal fertigation effects on growth, yield and nutrient use efficiency of elephant foot yam (Amorphophallus paeoniifolius). American-Eurasian J. Agric. Environ.
Sci. 17(1): 63-77.

Nedunchezhiyann M., Mukherjee, A., Byju, G., Ravi, V. and James George. 2016. Growth, dry matter production and nutrient uptake of elephant foot yam (Amorphophallus paeoniifolius(Dennst.) Nicolson) as influenced by drip irrigation and fertigation levels. J. Root Crops 42(1): 22-32.

Nedunchezhiyan, M. 2017. Drip irrigation and fertigation effects on corm yield, water and fertilizer use efficiency and economics in elephant foot yam (Amorphophallus paeoniifolius). Indian J. Agron. 62(4): 519-524.

Nedunchezhiyan, M. 2014a. Crop architecture effects on elephant foot yam (Amorphophallus paeoniifolius) productivity and economics under rainfed conditions. Indian J. Agron. 59(1): 122-127.

Nedunchezhiyan, M. 2014b. Production potential of intercropping spices in elephant foot yam (Amorphophallus paeoniifolius). Indian J. Agron. 59(4): 596-601.

Nedunchezhiyan, M. and Byju, G. 2005. Productivity potential and economics of elephant foot yam based cropping system. J. Root Crops 31(1): 34-39.

Nedunchezhiyan, M., Byju, G. and Naskar, S.K. 2008. Yield potential and economics of elephant foot yam (Amorphophallus paeoniifolius) + greengram (Vigna radiata) intercropping system as influenced by mulching and fertilizer levels. Indian J. Agric. Sci. 78(1): 17-20.

Nedunchezhiyan, M., Byju, G., Ravi, V. and James George. 2018. Effect of fertigation schedule on production potential, quality and nutrient uptake of elephant-foot yam (Amorphophallus paeoniifolius). Cur. Hort. 6(1): 19-26.

Palaniswamy, U. R., Bible, B. B. and McAvoy, R. J. 2002. Effect of nitrate: 
ammonium nitrogen ratio on oxalate levels of purslane. In: Janick $\mathrm{J}$, Whipkey A (eds.). Trends in new crops and new uses. ASHS Press. Alexandria, VA.

Palaniswamy, U. R., Bible, B. B. and McAvoy, R. J. 2004. Oxalic acid concentrations in purslane (Portulaca oleraceae L.) is altered by the stage of harvest and the nitrate to ammonium ratios in hydroponics. Scientia Hort. 102: $267-275$.

Parkinson, S. 1984. The contribution of aroids in the nutrition of people in the South Pacific, In: S. Chandra (ed.). Edible aroids. Clarendon Press, Oxford: pp 215-224.

Patel N and Rajput T B S. 2000. Effect of fertigation on growth and yield of onion. (In) Proceedings of International Conference on Micro and Sprinkler Irrigation Systems, 8-10 February 2000, Jalgaon, Maharashtra, India, pp. 77.

Patel, B. M. and Mehta, H. M. 1987. Effect of farm yard manure, spacing and nitrogen application on chemical constituents of elephant foot yam (Amorphophallus campanulatus). Gujarat Agricultural Univ. Res. J. 13(1): 46-47.

Sakai, W. S. 1983. Aroid root crops: Allocasia, Cyrtosperma and Amorphophallus, In: H.T. Chan (ed.). Handbook of tropical foods. Marcel Dekker, New York: pp 29-83.

Singh R., Bhushan, S., Santosh, K. and Ravi, S. 2013. Yield assessment of elephant foot yam grown under multilayer vegetable cropping system. The bioscan 8(4): 1237-1240.

Singh, S. D., Singh, Y. V. and R. C. Bhandari. 1989. Tomato yield as related to drip lateral spacing and fertilizer application on total and wetted area basis. Can.J. Plant Sci. 69: 991-999.

Ukom, A. N., Ojimelukwe, P. C. and Okpara, D. A. 2009. Nutrient composition of selected sweet potatoes [Ipomoea batatas (L) Lam] varieties as influenced by different levels of Nitrogen fertilizer application. Pakistan J. of Nutrition 8(11): 1791-1795.

\section{How to cite this article:}

Jata, S.K., M. Nedunchezhiyan, S.K. Maity and Mallikarjun, M. 2020. Drip Fertigation Effects on Quality Characters of Elephant Foot Yam and Water Use Efficiency of Elephant Foot Yam+Green Gram Intercropping System. Int.J.Curr.Microbiol.App.Sci. 9(08): 1307-1316. doi: https://doi.org/10.20546/ijcmas.2020.908.148 